\title{
МАГНІТОРЕЗИСТИВНІ ВЛАСТИВОСТІ ПЛІВКОВИХ МАТЕРІАЛІВ ЕЛЕКТРОНІКИ З РІЗНОЮ АРХІТЕКТУРОЮ
}

\section{Однодворець Л. В., Проценко І. Ю.}

\section{ВСТУП}

Широке використання плівкових матеріалів у мікроелектроніці, спінтроніці і сенсорній техніці постійно стимулює дослідження їхніх фізичних властивостей та вивчення температурних і концентраційних ефектів у електрофізичних та магніторезистивних властивостях, оскільки в таких системах можуть стабілізуватися гранульовані й упорядковані тверді розчини (т. р.) та інтерметалідні фази, формуватися магнітні інтерфейс ${ }^{1,2}$. Під впливом температури і зовнішнього магнітного поля проявляються особливості взаємодії носіїв заряду з межами поділу, магнітними моментами атомів, гранул $\mathrm{i}$ доменів та фононами. Встановлення особливостей впливу різних факторів на фізичні властивості багатошарових, гранульованих i багатокомпонентних, у т.ч. високоентропійних, плівкових матеріалів необхідне для створення елементів сенсорної електроніки, оптоелектроніка i спінтроніки ${ }^{3,4,5}$. Дуже важливим $\epsilon$ вивчення особливостей формування структурно-фазового складу плівок

${ }^{1}$ Campbell I.A., Fert A. Transport properties of ferromagnets. Ferromagnetic Materials. Edited by E.P.Wohlfarth. 1982. V.3. P .747-800.

2 Grunberg P., Schreiber R., Pang Y.,. Brodsky M.B, Sowers H. Layered magnetic structures: evidence for antiferromagnetic coupling of $\mathrm{Fe}$ layers across $\mathrm{Cr}$ interlayers. Phys. Rev. Lett. 1986. V. 57, № 19. P. 2442-2445. DOI 10.1103/PhysRevLett.57.2442

3 Ферт А. Происхождение, развитие и перспективы спинтроники. Усnехи физики металлов. 2008. Т. 172, № 12. С. 1336-1348.

${ }^{4}$ Berkowitz A. E., Mitchell J.R. , Carey M. J., Young A.P., Zhang S., Spada F.E., Parker F.T., Hutten A., Thomas G. Giant magnetoresistance in heterogeneous Cu-Co alloys. Phys. Rev. Lett. 1992. V. 68, № 25. P. 3745-3748. DOI 10.1103/PhysRevLett.68.3745.

${ }^{5}$ Грюнберг П.А. От спиновых волн к гигантскому магнитосопротивлению и далее. Успехи физики металлов. 2008. Т. 172, № 12. С. 1349-1358. 
в умовах термообробки, впливу магнітного поля ${ }^{6,7}$. Зауважимо, що мультишари, гранульовані плівкові матеріали і високоентропійних сплавів (BEC) належать до систем, у яких спін-залежне розсіювання електронів (СЗРЕ) провідності реалізується в ефект гігантського магнітоопору (ГМО). Перехід до магніторезистивних структур відбувається, коли домінує внесок у величину МО дає СЗРЕ на інтерфейсах або на магнітних гранулах систем на основі магнітних $\mathrm{i}$ немагнітних металів порівняно 3 розсіюванням електронів на магнітних моментах доменів або їхніх стінках.

Розроблений близько десяти років тому новий клас металевих т.p., т. зв. ВЕС, $\epsilon$ унікальним класом багатокомпонентних матеріалів ${ }^{8,9,10}$. ВЕС містять не менш 5 основних металевих елементів, атомний відсоток кожного з яких складає від 5 до 35\%. В отриманих сплавах відбувається формування однофазного стабільного твердого розчину заміщення (переважно ГЦК- або ОЦК-гратки), який є одночасно високоміцним і термодинамічно стійким. Причина цього - висока ентропія змішування, яка забезпечує стабілізацію утворення твердого розчину й запобігає формування інтерметалідних фаз у процесі кристалізації11. Властивості ВЕС значною мірою визначаються впливом процесів, які не завжди притаманні традиційним багатоелементним сплавам, а саме: вплив ентропії змішування; вплив викривлення кристалічної гратки сформованого твердого розчину; вплив уповільненої дифузії

${ }^{6}$ Tiwari A. Effect of addition of $\mathrm{Ni}$ on the structure and giant magnetoresistance in $\mathrm{Fe}-\mathrm{Cu}$ films. Physica B: Condens. Matter. 2007. V. 387. P. 63-68. DOI 10.1016/j.physb.2006.03.029.

${ }^{7}$ Hiep V.V. , Chau N. , Hong D.M. , Luong N. H. High coercivity and giant magnetoresistance of $\mathrm{CoAg}, \mathrm{CoCu}$ granular films. J. Magn. Magn. Mater. 2007. V. 310. P. 2524-2526. DOI 10.1016/j.jmmm.2006.11.136.

${ }^{8}$ Yeh J. W., Chen Y. L., Lin S. J., Chen S. K. High-Entropy Alloys - A New Era of Exploitation. Mater. Sci. Forum. 2007. V. 560. P. 1-9. DOI 10.4028/ www.scientific.net/MSF.560.1

${ }^{9}$ Vorobiov S.I., Kondrakhova D.M., Nepijko S.A., Poduremne D.V., Shumakova N.I., Protsenko I.Yu. Crystalline structure, electrophysical and magnetoresistive properties of high entropy film alloys. J.Nano- Electron. Phys. 2016. V. 8, № 3. P. 03026-1-03026-5. DOI 10.21272/jnep.8(3).03026.

${ }^{10}$ Bereznyak Yu.S., Opielak M., Odnodvorets L.V., Poduremne D.V., Protsenko I.Yu., Shabelnyk Yu.M. Crystalline structure and physical properties of high-entropy film alloys. J. Nano- Electron. Phys. 2019. V.11, № 2. P. 02026-1-02026-6. DOI 10.21272/jnep.11(2).02026

${ }_{11}$ Yeh J.-W. Recent progress in high-entropy alloys. Ann. Chim. Sci. des Matériaux. 2006. V. 31. № 6. P. 633-648. DOI 10.3166/acsm.31.633-648. 
та ефект перемішування. Висока температурна стабільність ВЕС забезпечує перспективи їх використання для пасивних елементів інтегральних мікросхем із наперед заданою структурою шарів та значенням робочих параметрів.

\section{1. Методика підготовки зразків та магніторезистивні властивості багатошарових плівкових матеріалів}

Особливу увагу дослідників привертають плівкові системи, в яких відбувається утворення необмежених т.p. із можливою подальшою стабілізацією в них гранульованого стану ${ }^{12}$. Це пов'язано із спостережуваним в таких системах явищем ГМО, де переважає спін-залежне розсіювання носіїв електричного струму на гранулах магнітної компоненти, що розташована в немагнітній матриці. Нами вивчалися магніторезистивні властивості двокомпонентних або багатошарових плівкових систем на основі $\mathrm{Co}, \mathrm{Fe}, \mathrm{Cu}, \mathrm{Ag}, \mathrm{Au}$ та інших металів, які отримувалися в вакуумній камері ( $p=10^{-3}-10^{-4}$ Па). Осадження проводилось при температурі $300 \mathrm{~K}$ на підкладки (П) із аморфного ситалу або природно оксисленого $\mathrm{Si}$ (для магніторезистивних досліджень) та на скол кристалу $\mathrm{NaCl}$, на який попередньо було осаджено плівку вуглецю товщиною приблизно 30 нм (для електронно-мікроскопічних досліджень). Спеціальна система заслінок дає змогу в одному технологічному процесі отримувати як одношарові плівки, так і багатошарові системи, у т.ч. і ВЕС, методами одночасної або пошарової конденсації компонент.

У випадку систем з обмеженою взаємною розчинністю для утворення твердих розчинів застосовувались методи одночасного осадження компонент (Co або Fe i Ag) або пошарового осадження надтонких шарів (товщиною $d=0,5-3$ нм). У випадку систем iз необмеженою взаємною розчинністю компонент методом послідовної конденсації шарів із наступною термообробкою були одержані гранульовані т.p. $\mathrm{Cu}$ (Со). Товщина окремих шарів плівкової системи контролювалася двома методами: у процесі конденсації за допомогою кварцового резонатора, а після осадження - методом оптичної інтерферометрії.

12 Arana S., Castafto E., Gracia F.J. High temperature circular position sensor based on a giant magnetoresistance nanogranular AgxCo1-x alloy IEEE Sens. J. B. 2004. V. 4. P. 221-225. 
Концентрація і-ої компоненти у плівкових матеріалах обраховувалась, виходячи з їх ефективної товщини $\left(d_{\mathrm{i}}\right)$ :

$$
c_{i}=\frac{\rho_{i} d_{i} \mu_{i}^{-1}}{\sum_{i=1}^{n} \rho_{i} d_{i} \mu_{i}^{-1}},
$$

де $\rho_{i}$ - густина, $\mu_{i}$ - молярна маса відповідного елементу, $n$ - загальне число компонент, а потім уточнювалась методом енерго-дисперсійного аналізу. Відпалювання зразків проводилось в інтервалі температур від 300 до 900 К. Подальші дослідження структурно-фазового стану i проведення електронографічного аналізу проводились за допомогою просвічуючого електронного мікроскопу після охолодження зразків до $300 \mathrm{~K}$.

Дослідження магніторезистивних властивостей проводилося при кімнатній температурі 3 використанням чотириточкової схеми в зовнішньому магнітному полі від 0 до 600 мТл. При цьому струм був направлений паралельно площині зразка, а вимірювання магнітоопору проводилися у трьох геометріях - поздовжній (лінії магнітної індукції $B$ направлені вздовж напряму протікання струму), поперечній (лінії $B$ направлені перпендикулярно до лінії протікання струму) та перпендикулярній (лінії $B$ перпендикулярні площині зразка). Величина магнітоопору визначалася за співвідношенням $\mathrm{MO}=\Delta R / R(0)=(R(\mathrm{~B})-R(0)) / R(0)$, де $R(\mathrm{~B})$ і $R(0)-$ опір плівки при заданому полі і без поля. Для оцінки анізотропного магнітоопору нами використовувалося співвідношення $\mathrm{AMO}=3 \Delta R /(R(\mathrm{~B}) \|+2 R(\mathrm{~B}) \perp)$, де $R(\mathrm{~B}) \|$ i $R(\mathrm{~B}) \perp$ - значення опору плівки при паралельній і поперечній геометрії вимірювання МО.

Магніторезистивні властивості плівкових систем на основі Fe i $\mathrm{Cr}$ або $\mathrm{Cu}$ вивчались на прикладі мультишарів $[\mathrm{Fe} / \mathrm{Cr}]_{n} / \Pi$ та $[\mathrm{Fe} / \mathrm{Cu}]_{n} / \Pi$, де $n=15$ - кількість фрагментів, яка за даними ${ }^{13}$ $\epsilon$ оптимальною. Для плівкової системи $[\mathrm{Fe} / \mathrm{Cu}]_{15-30} / П$ показано, що при загальній товщині системи 70-100 нм спостерігається насичення залежностей $\Delta R / R(0)$ i $B_{s}$ від загальної товщини. Дані магніторезистивних вимірювань в мультишарах $[\mathrm{Fe} / \mathrm{Cr}]_{\mathrm{n}} / \Pi$

${ }^{13}$ Baibich M.N., Broto J.M., Fert A., Vandau F.N., Petroff F., Eitenne P., Creuzet G. , Friederich A., Chazelas J. Giant magnetoresistance of $(001) \mathrm{Fe} /(001) \mathrm{Cr}$ magnetic superlattices. Phys. Rev. Lett. 1988. V.61. P. 2472-2475. DOI 10.1103/PhysRevLett.61.2472. 
представлені на рис. 1. Як видно, для двох плівкових систем 3 атомною концентрацією 45 і 50 ат.\% Fe характерна ізотропність польових залежностей $R(\mathrm{~B})$, тобто незалежно від геометрії вимірювання спостерігається зменшення величини електроопору в магнітному полі, що $\epsilon$ характерною ознакою ГМО. Для інших систем з тонкими ( $\leq 2$ нм) або відносно товстими (4 нм) шарами $\mathrm{Cr}$ характерна анізотропія залежностей $R(\mathrm{~B})$, подібно до феромагнітних плівок, і переважання величини магнітоопору (MO) в повздовжній геометрії у порівнянні з двома іншими геометріями. Термообробка зразків у широкому інтервалі температур $(300 \div 900$ К) в більшості випадків привела до незначного зростання величини МО у всій трьох геометріях при температурі відпалювання $T_{6}=500 \mathrm{~K}$ і спаданні - при подальшому відпалюванні до $900 \mathrm{~K}$, а також зникненню ознак ГМО в двох зразках при $T_{b}=900 \mathrm{~K}$. Необхідно відзначити великі значення $B_{\mathrm{s}}$ в системах 3 ознаками ГМО (> 200 мТл), що характерно для мультишарів із спін-залежним розсіюванням електронів. Особливості гістерезису в цих плівках виражаються в наявності подвійних піків на магніторезистивних петлях (рис. 1 а) i великим значеннями коерцитивності $B_{c}(3,3 \div 18,0$ мТл), що може пояснюватися перемагнічуванням шарів Fe. У анізотропних зразках на основі фрагменту $\mathrm{Fe} / \mathrm{Cr}$ спостерігається значне зменшення величини $B_{s}$ (до $30 \div 40$ мТл), що істотно впливає на чутливість МО до магнітного поля. Зазвичай величина чутливості $S_{B}$ у невідпалених зразках становить $0,4 \div 3 \% /$ Тл, а для відпалених до 900 К не перевищує 0,9\%/Тл. У мультишарах на основі $\mathrm{Fe}$ i $\mathrm{Cu}^{14}$ (рис. 2) при атомній концентрації $c_{\mathrm{Fe}}>50$ ат.\% спостерігається анізотропія польових залежностей $R$ від $B$, а, як наслідок, і $\Delta R / R_{\mathrm{s}}$ від $B$.

Необхідно відзначити, що для величина МО в більшості випадків не перевищує $0,05 \%$. При менших значеннях $c_{\mathrm{Fe}}$ анізотропія зникає, а величина МO значно збільшується (для $[\mathrm{Fe}(1,6) / \mathrm{Cu}(1,7)]_{15} / \Pi$ $\left.\left(c_{\mathrm{Fe}}=48 \%\right) \Delta R / R_{\mathrm{s}}=0,1 \div 0,2 \%\right)$, що може свідчити про наявність ГМО в мультишарах на основі фрагмента $\mathrm{Fe} / \mathrm{Cu}$.

14 Кондрахова Д.М., Шабельник Ю.М., Синашенко О.В., Проценко І.Ю. Структурно-фазовий стан, електрофізичні та магнеторезистивні властивості твердих розчинів у плівкових системах на основі Co i $\mathrm{Cu}$ aбо $\mathrm{Ag}$ та $\mathrm{Fe} \mathrm{i} \mathrm{Cr}$ або Сu. Успехи физики металлов. 2012. Т. 13, № 3. С. 241-267. 

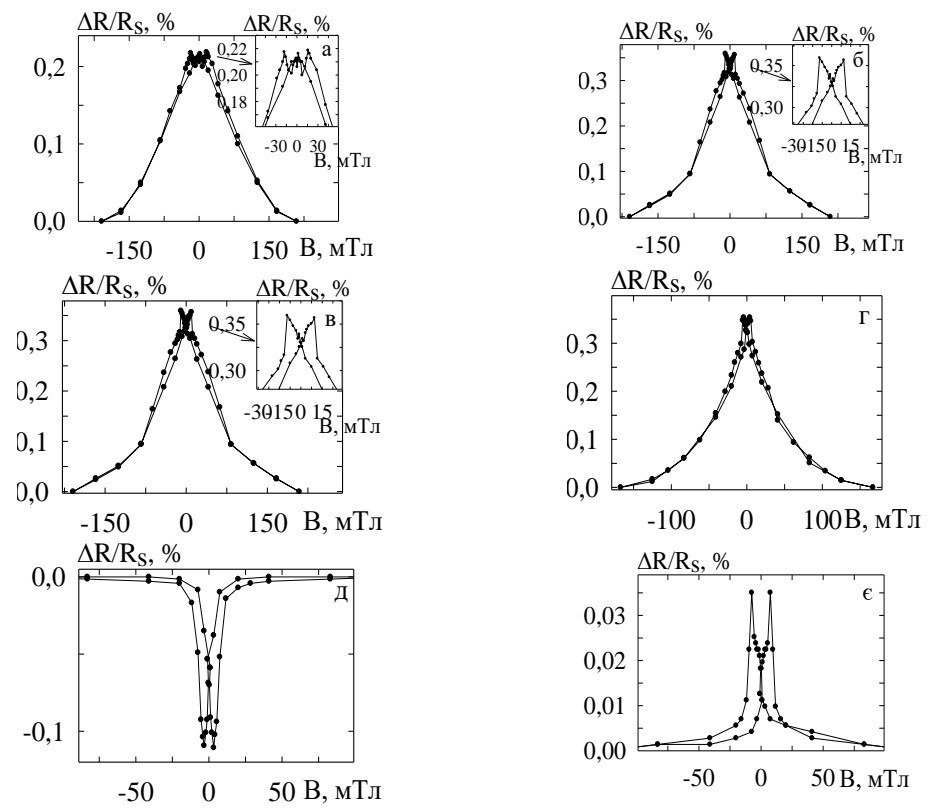

Рис. 1. Залежність МО від індукції магнітного поля для плівкової системи $[\mathrm{Fe}(2,3) / \mathrm{Cr}(2,8)]_{15} /$ П: невідпаленої $(\mathbf{a}$, б) і відпаленої до $T_{b}=500$ (в, г) і 900 К (д, є) в двох геометріях - повздовжній $(\mathrm{a}, \mathrm{B}$, д) і поперечній $(\boldsymbol{\sigma}, \Gamma, \epsilon)$. У дужках вказана товщина в нм

Термообробка зразків до $850 \mathrm{~K}$ приводить до незначного зменшення магніторезистивного ефекту в трьох геометріях, а за рахунок переважного зростання поля насичення $B_{\mathrm{s}}-$ до зменшення чутливості $S_{B}$. Також необхідно відзначити наявність на магніторезистивних залежностях гістерезису i магнітного насичення при малих полях, що спричиняє досить великі значення чутливості до магнітного поля (в зразках із $d_{\mathrm{Cu}}=1,7 \mathrm{HM}$ величина $S_{B}$ досягає 0,6-14 \%/Тл). У випадку плівкової системи на основі Со і $\mathrm{Cu}$ магніторезистивні властивості досліджувались для тришарових структур $\mathrm{Co} / \mathrm{Cu} / \mathrm{Co} / \Pi$ (рис. 5) із різною концентрацією магнітної компоненти. Характерним для них є відсутність анізотропії МО в залежності від геометрії вимірювання, що, як вже зазначалось, являється ознакою ГМО. Відмітимо, що перехід анізотропний $\mathrm{MO} \rightarrow$ ГМО проходить у випадку, коли домінуючий внесок у величину МО вносить спін-залежне розсіювання електронів провідності на інтерфейсах магнетик/немагнітний метал або магнітних 
гранулах у порівнянні із розсіюванням на магнітних моментах доменів та їх стінках. Слід відмітити, що магніторезистивні властивості розглянутих нами плівкових систем $\mathrm{Co} / \mathrm{Cu} / \mathrm{Co} / \Pi$ термостабільні: після відпалювання до $T_{b}=700 \mathrm{~K}$ спостерігається незначне зменшення величини $\mathrm{MO}$, що також характерно і для величини поля насичення $B_{\mathrm{s}}$. Водночас термообробка зразків $\mathrm{Co}(14) / \mathrm{Cu}(9) / \mathrm{Co}(14) / \Pi$ (рис. 3) призводить до зменшення магніторезистивного ефекту в перпендикулярній геометрії та його збільшення в інших геометріях, що також притаманно і для індукції $B_{\mathrm{s}}$ магнітного поля (від 140 до 24 мТл - в перпендикулярній, та від 35 до 39 мТл - в повздовжній

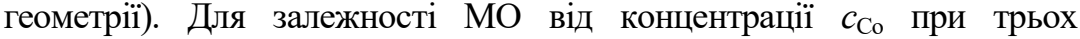
геометріях вимірювання характерне збільшення значення МО з ростом концентрації атомів Со в системі. Особливо це помітно у випадку поперечної геометрії, в якій при концентрації $c_{\mathrm{Co}}=60$ ат.\% МО становить $0,2 \%$, та при 87 ат.\% - 0,4\%. Якщо порівнювати значення індукції насичення при різних геометріях, то зазначимо, що для перпендикулярної воно є найбільшим, що пояснюється присутністю в цій геометрії вісі важкого намагнічування.
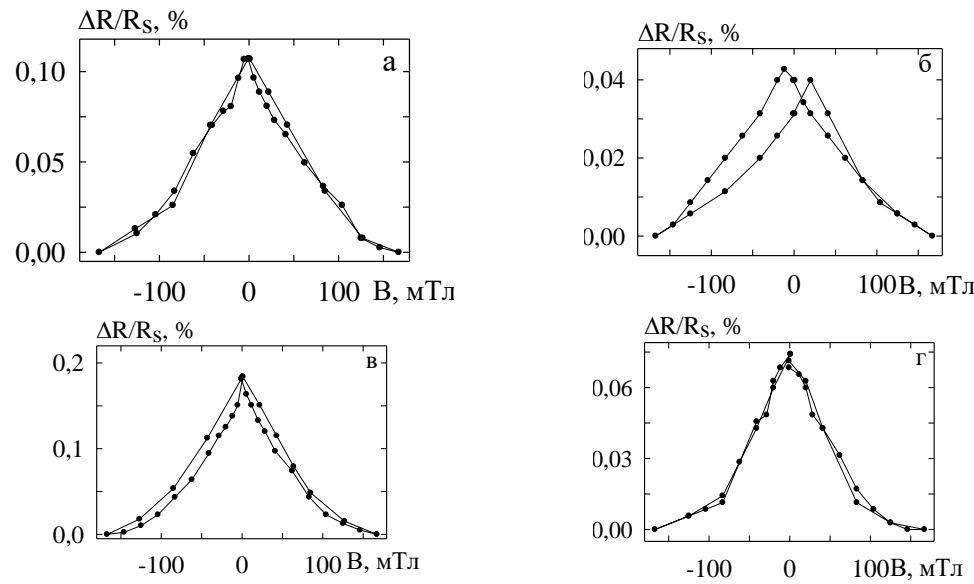

Рис. 2. Залежність МО від індукції магнітного поля для плівкової системи $[\mathrm{Fe}(1,6) / \mathrm{Cu}(1,7)]_{15} /$ П: невідпаленої $(\mathrm{a}, \mathrm{B})$ та відпаленої до $T_{6}=850$ К (в, г) у повздовжній $(\mathrm{a}$, б) і поперечній $($ в, г) геометріях

Досліджувані плівкові системи при значеннях $\mathrm{MO}=0,1-0,4 \%$ характеризуються досить великими значеннями величини чутливості до магнітного поля. Найбільше значення $S_{B}$ зафіксовано для системи $\mathrm{Co}(14) / \mathrm{Cu}(9) / \mathrm{Co}(14) / \Pi$ і складає $22 \% /$ Тл в поперечній геометрії. 
У випадку зменшення товщини проміжного немагнітного шару $\mathrm{Cu}$ від 9 до 6 нм поле коерцитивності зменшується від 200 до 100 мТл, відповідно, значення чутливості магнітного поля при цьому збільшується від 1,2 до 2,8 \%/мТл. Із даних результатів витікає, що нижній магнітний шар дає більший внесок у величину $\mathrm{MO}$, i збільшення його товщини призводить до збільшення коерцитивності системи.

\section{2. Магніторезистивні властивості гранульованих плівкових сплавів}

Потреби стрімкого розвитку сучасного напряму магнітоелектроніки - спінтроніки виявили цілу низку нових невирішених задач у фізиці плівкового матеріалознавства.
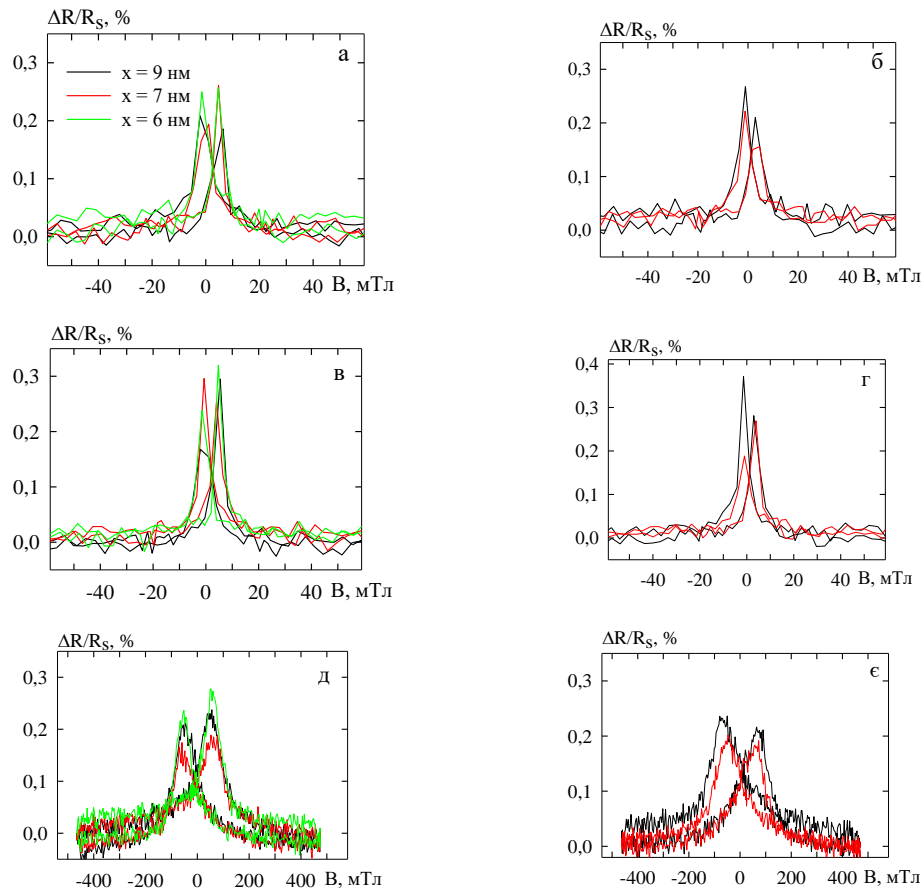

Рис. 3. Залежність МО від індукції магнітного поля для плівкової системи $\operatorname{Co}(14) / \mathrm{Cu}(x) / \operatorname{Co}(14) / П$, невідпаленої $(\mathrm{a}, \mathrm{B}$, д) та відпаленої до $T_{\mathrm{в}}=700$ К $(б, \Gamma, \epsilon)$, у поздовжній $(\mathrm{a}, \boldsymbol{\sigma})$, поперечній $(\mathrm{в}$, г) та перпендикулярній (д, с) геометріях вимірювання. $x=6,7,9$ нм 
По-перше, оскільки елементи спінтроніки функціонують під дією зовнішніх магнітних полів, виникла потреба в нових швидкодіючих та високоточних датчиках магнітних полів різних діапазонів. По-друге, вже відомі функціональні елементи мають ряд недоліків, що зумовлені їхньою нестабільністю під впливом зовнішніх фізичних полів. Для вирішення цих питань постійно 3'являються пропозиції застосування принципово нових магнітних матеріалів, наприклад супермолекулярних, графенових, на основі магнітних напівпровідників, наночастинок i т.д. Процеси спінзалежного розсіювання електронів у приладових структурах спінтроніки протікають у площині меж поділу окремих магнітних $\mathrm{i}$ немагнітних шарів. Тому властивості всієї системи залежать від методу іiі отримання та особливостей формування меж поділу між шарами. Так, відомо, що в мультишарах на основі ультратонких магнітних i немагнітних шарів під час повільної конденсації утворюються супергратки, а застосування швидкого термічного осадження призводить до утворення твердих розчинів в тих же системах.

Двокомпонентні гранульовані сплави можна отримати двома методами. Традиційним став метод одночасної конденсації із двох джерел $\left(\mathrm{Me}_{1}+\mathrm{Me}_{2} / \Pi\right)$, якій у роботі був використаний для отримання гранульованих плівкових сплавів. В інший спосіб отримати гранульований стан плівкових зразків можна використовуючи методику пошарової конденсації $\left(\mathrm{Me}_{2} / \mathrm{Me}_{1} / \Pi\right) \quad 3$ подальшим відпалюванням до різних температур $(400-900$ К), що відбувається 3 постійною швидкістю нагрівання-охолодження $2 \mathrm{~K} / \mathrm{xв}$ та ізотермічним відпалюванням при заданій температурі протягом 15 хвилин. Особливо підкреслимо, що за таких методів формування вказаних типів плівкових систем у них можлива реалізація МО, анізотропного магнітоопору (AMO) та ефекту ГМО. Щоб уникати впливу структури підкладки на структуру досліджуваних плівок $\mathrm{i}$, як наслідок цього, наприклад, на іiі магнітну анізотропію, як підкладки використовувалися пластини кремнію із природним шаром оксиду. У деяких плівкових системах можлива реалізація умов формування гранульованого стану магнітної компоненти ${ }^{15}$. Найбільшу схильність до цього, як показують дослідження, виявили

15 Koltunowicz T.N., Bondariev V., Odnodvorets L.V., Protsenko S.I., Shumakova M.O., Tkach O.P. Electrophysical properties of granular film alloys. Vacuum. 2019. V. 164. P.165-169. DOI 10.1016/j.vacuum.2019.04.015. 
системи на основі Со та $\mathrm{Cu}$ і меншою мірою - на основі Со і $\mathrm{Au}$ або Ag. На рис. 4 наведена мікроструктура гранульованого т.p. Ag (Co) та відповідна електронограма.

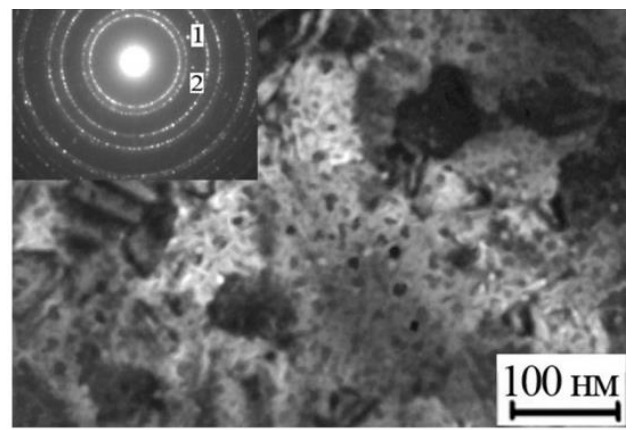

Рис. 4. Мікроструктура та відповідна йй електронограма гранульованого стану т.p. $\mathrm{Ag}(\mathrm{Co})$, сформованого на основі двошарової плівкової системи $\mathrm{Ag}(40) / \mathrm{Co}(30) /$ П. Цифрами 1 і 2 позначені рефлекси від гранул Со

Гранульовані сплави, на відміну від інших структур, не мають у своєму складі структурно суцільних шаруватих утворень магнітної компоненти 3 доменною структурою. Магнітні гранули в цих сплавах мають широкий діапазон магнітного поля перемагнічування. Тому площа під кривою МО набагато більша, ніж в інших випадках. На рис. 5 представлені залежності МО при поздовжній геометрії вимірювання для плівкових систем $\operatorname{Co}(10) / \operatorname{Ag}(20) / \operatorname{Co}(10) / \Pi$ та $\operatorname{Co}(6) / \operatorname{Au}(15) / \operatorname{Co}(5) / \Pi$, відпалених до $T_{\text {в }}=800 \mathrm{~K}$, у яких відбулося утворення гранул. Для МО плівкових гранульованих сплавів на основі $\mathrm{Ag}$ та Со характерна величина $0,40-0,50 \%$ при загальній концентрації $c_{\mathrm{Co}}=38$ ат.\%, а при збільшенні концентрації атомів Со величина МО спочатку зростає майже в три рази $\left(\mathrm{MO}=1,5-1,8 \% ; \quad c_{\mathrm{Co}}=60\right.$ ат.\%), а потім зменшується $\left(\mathrm{MO}=0,4-0,5 \% \quad\right.$ при $\quad c_{\mathrm{Co}}=70$ ат.\%) (рис. 5). Термовідпалювання призводить до незначного зростання величини MO при $T_{\mathrm{B}}=800 \mathrm{~K}$ та його зменшення при $T_{\mathrm{B}}=900 \mathrm{~K}$ у всіх трьох геометріях вимірювання МО. На рис. 6 наведені залежності для МО від індукції зовнішнього магнітного поля свіже сконденсованих та термостабілізованих до $750 \mathrm{~K}$ плівок $(\mathrm{Fe}+\mathrm{Ag}) / \Pi$ із загальною концентрацією $c_{\mathrm{Ag}}=70$ ат.\%. 


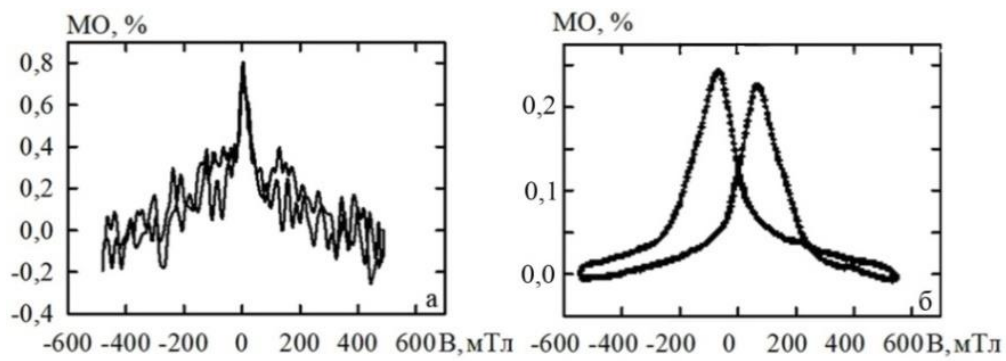

Рис. 5. Залежність МО від індукції магнітного поля при поздовжній геометрії вимірювання для плівкових систем

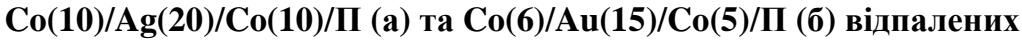
до $T_{\mathrm{B}}=800 \mathrm{~K}$
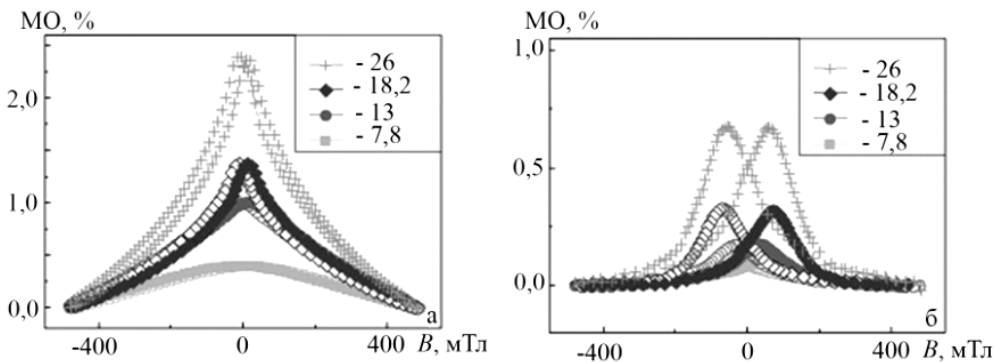

Рис. 6. Залежність МО від індукції зовнішнього магнітного поля для плівкової системи (Fe+Ag)/П при загальній концентрації $c_{\mathrm{Ag}}=70$ ат.\% у невідпаленому (а) та відпаленому до $T_{\mathrm{B}}=750$ К (б) станах при поздовжній геометрії вимірювання МО. На вставці вказана загальна товщина в нм

Характерна для гранульованого сплаву залежність МО від зовнішнього магнітного поля спостерігається нами в невідпалених плівкових зразках із досить високими значеннями МО при кімнатній температурі вимірювання. Зменшення величини МО (рис. 6 б) після відпалювання можна пов'язати зі збільшенням середнього розміру гранул $\alpha$-Fe, що зменшує ефективність спінзалежного розсіювання електронів. У плівках на основі $\mathrm{Au}$ i Co магнітні гранули Со мають дещо менші розміри, про що свідчать, 
наприклад, дані роботи ${ }^{16}$, згідно з якими розміри гранул ГЩП-Со у сплаві, отриманому методом одночасної конденсації компонент, змінюються в межах 2,5-10 нм у залежності від температури термообробки. Таким чином, у плівкових системах 3 обмеженою розчинністю компонент типу $\left(\mathrm{Me}_{1}+\mathrm{Me}_{2} / \Pi\right)$, як правило, стабілізуються лише обмежені тверді розчини із або тверді розчини без елементів гранульованого стану.

\section{3. Магнітоопір і гігантський магнітоопір у високоентропійних плівкових сплавах}

В останнє десятиліття проводяться інтенсивні дослідження кристалічної структури і механічних властивостей нового класу матеріалів - високоентропійних сплавів (BEC), на покращені властивості яких вперше звернули увагу автори ${ }^{17}$. Оскільки ці сплави формуються на основі 5-13 елементів (в основному це ГЦК і тугоплавкі ОЦК або ГЩК метали), то вони мають високу ентропію змішування $\left(\Delta \mathrm{S}_{\mathrm{mix}}\right)$, у ВЕС виявляються більш стійкіми фази у вигляді ОЦК чи ГЦК т.р. у порівнянні 3 інтерметалідними сполуками та іншими складними структурами. Залежно від концентрації окремих компонент (наприклад атомів $\mathrm{Ni}$ ) може одночасно стабілізуватися ГЦК і ОЦК тверді розчини, де ОЦК може бути т.p. $\alpha-\mathrm{Fe}(\mathrm{Cr})$ або інтерметалід $\mathrm{AlNi}^{18}$. Аналіз дозволяє зробити висновок, що стабілізація ГЦК або ОЦК повністю визначається середньою концентрацією валентних електронів на атом, розміщених у валентній зоні сплаву: при концентрації меншій 7,2 ел/ат утворюється ОЦК фаза, при 7,2 - 8,2 ел/ат - стабілізується двофазовий склад ГЦК+ОЦК, і при концентраціях, більших 8,2 ел/ат - ГЦК, - фаза т.р. ВЕС. У нітридній фазі ВЕС на основі Al, $\mathrm{Cr}, \mathrm{Nb}$, Ti та напівпровідника $\mathrm{Si}$ також стабілізується ГЦК фаза. Формування однофазного твердого розчину заміщення, замість

${ }^{16}$ Vrenken H., Kooi B.J., de Hosson T.M. Microstructure and properties of giant magnetoresistance granular Au80Co20 alloys. J. Appl. Phys. 2001. V. 89, № 6. P. 3381-3388. DOI 10.1063/1.1325381.

${ }^{17}$ Yeh J. W., Chen S. K., Lin S. J., Gan J. Y., Chin T. S., Shun T. T., Tsau C. H., Chang S. Y. Nanostructured high-entropy alloys with multiple principal elements: novel alloy design concepts and outcomes. Adv. End. Mater. 2004. V.6. P. 299-303. DOI 10.1002/adem.200300567.

${ }^{18}$ Карпець М.В., Макаренко О.С., Мисливченко О.М., Горбань В.Ф. Вплив $\mathrm{Ni}$ на фазовий склад, мікроструктуру та механічні властивості системи високоентропійних сплавів AlCrCoCuFeNix $(\mathrm{x}=0 ; 0,5 ; 1 ; 2 ; 3)$. Наукові вісті НТУУ «КПI». 2014. Т.2. № 46. С. 46-52. 
формування багатофазного з'єднання, суперечить правилу фаз Гіббса, яке визначає кількість фаз залежно від кількості елементів (зокрема, в шести- або семиелементних системах повинно формуватися, мінімум, сім або вісім рівноважних фаз відповідно). Однак вищевказане правило не діє у випадку ВЕС, тому що в їхньому випадку формування фазово-структурного складу регулюється ентропією змішування.

У випадку відхилення середнього атомного радіуса $\bar{r}=\sum_{i=1}^{n} c_{i} r_{i}$. викривлення кристалічних граток впливають на напруженодеформований стан матеріалу, що позначається на властивостях одержуваних матеріалів. Зміною концентрації лише одного складового елементу 3, наприклад, п'яти можна добитися зміни структури від аморфної до кристалічної, а за властивостями збільшення питомого електричного опору внаслідок зміни щільності точкових дефектів. Той факт, що кожен атом складового елемента ВЕС може 3 однаковою ймовірністю зайняти той або інший вузол у кристалічній гратці, впливає на кінетику дифузії. Різнорідність атомів приводить до зміни потенціальної енергії між вузлами кристалічних граток. Таким чином, у ВЕС спостерігається мінімальний коефіцієнт дифузії. Це впливає на безліч факторів, наприклад, ріст зерен відбувається повільніше, збільшується міцність під час термічної обробки, більшою $\epsilon$ ймовірність формування наноструктур i нанорозмірних формувань. Остання особливість ВЕС - це наявність так званого ефекту перемішування. У деяких випадках у ВЕС формуються, окрім основної фази, інші як упорядковані, так і неупорядковані - фази.

Нами використовувались два варіанти формування плівкових BEC: одночасна та пошарова конденсація. Перший варіант реалізується шляхом одночасної подачі напруги (до 20 В) на всі випарники. Плівкові ВЕС (загальна товщина зразка до 100 нм) на основі $\mathrm{Fe}, \mathrm{Ni}, \mathrm{Co}, \mathrm{Cu}$, Al i $\mathrm{Cr}$ формувались 3 використанням вакуумної установки типу ВУП-5М (тиск $p \sim 10^{-3}-10^{-4}$ Па). Використовуються методи пошарової або одночасної конденсації 5-6-ти металів на підкладки із ситалу або $\mathrm{SiO}_{2} / \mathrm{Si}$. Під час пошарової конденсації товщина окремих шарів варіювалась від 10 до 30 нм. Товщини плівок контролюються in situ методом за допомогою кварцового резонатора типу РГ-08 з частотою 10 МГц (точність 10\%). Час відпалювання експериментальних зразків при максимальній температурі складає 15 хвилин, а швидкість охолодження - $3 \mathrm{~K} / \mathrm{xв}$. 
Після гомогенізації шляхом термічного відпалювання зразків формується ГЦК-фаза твердого розчину ВЕС із параметром $a=0,360-0,365$ нм (у сплавах на основі $\mathrm{Cu}, \mathrm{Cr}, \mathrm{Fe}, \mathrm{Ni}$ та Co) або $a=0,402-0,405$ нм (у сплавах на основі $\mathrm{Al}, \mathrm{Cr}, \mathrm{Fe}, \mathrm{Ni}$ та Co), тобто плівки стають однофазними. Вимірювання магнітоопору (МO) здійснювалося у трьох геометріях: поздовжній (вектор струму й індукції магнітного поля паралельні та лежать у площині плівки $(\vec{J} \| \vec{B}))$, поперечній $(\vec{J}+\vec{B})$ та перпендикулярній $(\vec{J} \perp \vec{B})$. Загальна товщина багатошарових плівок - 60-80 нм, робочий струм під час вимірювання опору - 10 мА. Енерго-дисперсійні спектри від зразків доводять високу чистоту отриманих плівок. Загальна характеристика плівкових ВЕС і результати вимірювання МО наведені в табл. 1.

Електронно-мікроскопічні дослідження вказують, що у вихідному стані (після конденсації) кристалічна структура виключно дисперсна

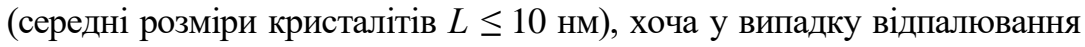
зразків до $850 \mathrm{~K}$ поряд із цією високодисперсною фракцією формується структура з величиною $L$ до 50 нм.

Характер електронограм вказує на те, що на стадії конденсації у плівкових ВЕС формується дві ГЦК і ОЦК фази (т. зв. фаза В2). Формування ГЦК1 і ГЦК2 фаз пов'язане з незакінченістю процесу формування т.р. ВЕС, хоча під час відпалювання зразків до $850 \mathrm{~K}$ відбувається гомогенізація сплаву і формування на основі ГЦК1 і ГЦК2 т.р. ВЕС із ГЦК решіткою.

Таблиця 1

Загальна характеристика зразків і результати вимірювання МО при T $=300 K$

\begin{tabular}{|c|c|c|c|c|}
\hline № & $\begin{array}{c}\text { Елементний склад зразків } \\
\text { після відпалювання } \\
\text { (концентрація, ат.\%) }\end{array}$ & $\mathbf{T}_{\mathbf{B}}, \mathbf{K}$ & $\begin{array}{c}\boldsymbol{R}, \text { Ом } \\
\text { при } \\
B=0 \text { Тл }\end{array}$ & MO, \% \\
\hline 1 & $\mathrm{Cu}_{15} \mathrm{Ni}_{23} \mathrm{Fe}_{22} \mathrm{Co}_{22} \mathrm{Al}_{18} / \Pi$ & 750 & 134.0 & $0.30(\perp)$ \\
\hline 2 & $\mathrm{Cu}_{15} \mathrm{Ni}_{25} \mathrm{Fe}_{20} \mathrm{Co}_{25} \mathrm{Al}_{15} / \Pi$ & 800 & $\begin{array}{l}152.0 \\
152.2\end{array}$ & $\begin{array}{l}0.08(+) \\
0.05(\perp)\end{array}$ \\
\hline 3 & $\mathrm{Co}_{20} \mathrm{Ni}_{14} \mathrm{Cu}_{20} \mathrm{Fe}_{28} \mathrm{Al}_{18} / \Pi$ & 800 & $\begin{array}{l}33.0 \\
25.0 \\
25.0\end{array}$ & $\begin{array}{l}0.15(\|) \\
0.17(+) \\
0.20(\perp)\end{array}$ \\
\hline 4 & $\mathrm{Co}_{20} \mathrm{Ni}_{25} \mathrm{Cu}_{20} \mathrm{Fe}_{20} \mathrm{Al}_{15} / \Pi$ & 800 & $\begin{array}{l}47.0 \\
48.0 \\
48.4\end{array}$ & $\begin{array}{l}0.15(\|) \\
0.17(+) \\
0.30(\perp)\end{array}$ \\
\hline
\end{tabular}


Скоріше за все одна із ГЦК фаз із самого початку формувалася як т.p. ВEC, а інша представляла собою метастабільну фазу на основі $\mathrm{Al} \mathrm{i} \mathrm{Ni,} \mathrm{яка} \mathrm{під} \mathrm{час} \mathrm{відпалювання} \mathrm{розпалася.} \mathrm{Термообробка}$ зразків сприяє заліковуванню дефектів і деякому впорядкуванню т.p. Рефлекси від оксидів $\mathrm{Al}_{2} \mathrm{O}_{3}$ та $\mathrm{Cr}_{2} \mathrm{O}_{3}$ мають точковий характер i малу інтенсивність, що пов'язано з малою ефективною товщиною шарів Cr i Al. Крім того, відмітимо, що від ОЦК фази (фаза В2) фіксуються дві дуже слабких лінії (200) і (220), і при цьому найбільш інтенсивна лінія (110) не фіксується. Середнє значення параметра ГЦК решітки т.р. дуже добре узгоджується з відповідним параметром для т.р. $\mathrm{Cu}(\mathrm{Ni}) a=0,352-0,366$ нм $^{19}$.

Дослідження МО у плівках ВЕС були проведені в геометрії СІР (струм у площині плівки) при трьох взаємних орієнтаціях магнітного поля: повздовжній, поперечній та перпендикулярній. Оскільки ГЦК т.р. ВЕС -типовий феромагнетик без елементів гранульованого стану, то в ньому має місце анізотропний магнітоопір (АМО). Ефект відпалювання до 800 К призводить до деякого збільшення амплітуди МО. Отримані результати однозначно вказують на реалізацію АMO із відносно малою амплітудою до $0,13 \%$, що пов'язано з малими товщинами плівок (до 40 нм). Велике значення $B_{\mathrm{c}}$, яке має місце в цьому випадку, розкидом розмірів гранул ${ }^{20}$, на яких, в силу різних причин, не реалізується СЗРЕ. На рис. 7 наведені типові залежності МО у трьох геометріях вимірювання на прикладі плівки $\mathrm{Co}_{22} \mathrm{Ni}_{15} \mathrm{Cu}_{20} \mathrm{Fe}_{30} \mathrm{Al}_{13} /$. Амплітуда МО складає 0,15-0,17\% у трьох геометріях вимірювання, а його польова залежність вказує на реалізацію ефекту ГМО. Ми робимо висновок, що таке розсіювання відбувається на квазігранулах, оскільки жодного іншого механізму не можна запропонувати.

Дослідження структурного та фазового стану, магніторезистивних властивостей плівкових ВЕС дозволяють зробити такі висновки: при конденсації плівок товщиною до 30 нм із подальшим відпаленням до $800 \mathrm{~K}$ можна сформувати однорідні плівки ВЕС 3 ГЦК граткою і параметрами, близькими до параметрів надлишкової

19 Калініченко С.М., Ткач О.П., Гричановська Т.М., Однодворець Л.В. Терморезистивні властивості плівкових твердих розчинів на основі $\mathrm{Cu}$ та $\mathrm{Ni}$. Ж. нано- та електронної фізики. Т. 7, № 4. 2015. С. 04048-1-04053-5.

20 Мазур Ю.П., Остапенко Р.В., Семенько М.П. Вплив різних типів деформацій на електроопір високоентропійного стопу CrMnFeCoNi. Наносистеми, наноматеріали, нанотехнологіï. 2016. Т. 14. № 4. С. 539-551. 
компоненти $\mathrm{Cu}$ або $\mathrm{Al}$; залежність $\mathrm{MO}$ від індукції магнітного поля має всі ознаки ГМО, завдяки чому можна зробити висновок про реалізацію в плівкових ВЕС спін-залежного розсіювання електронів. Відносно мала амплітуда ГМО пов'язана, перш за все, високою температурою вимірювання $(300 \mathrm{~K})$ та малою товщиною зразків.
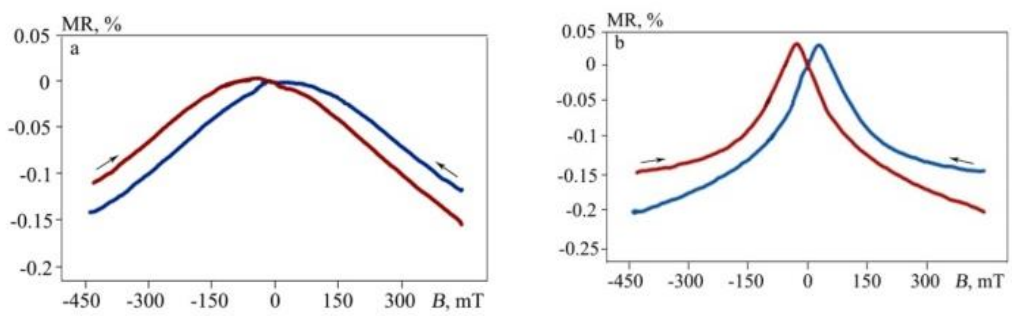

Рис. 7. Польові залежності МО для плівкового ВЕС, сформованого на основі системи $\mathrm{Co}(20) / \mathrm{Ni}(14) / \mathrm{Cu}(19) / \mathrm{Fe}(29) / \mathrm{Al}(18) / \Pi$ після відпалювання до 810 К поздовжньої (а) і перпендикулярної (б) геометрій вимірювання

\section{ВИСНОВКИ}

Нами проаналізовані літературні дані та результати власних досліджень магніторезистивних властивостей трьох типів плівкових матеріалів електроніки: багатошарових плівок, або мультишарів; гранульованих плівкових сплавів та багатокомпонентних (високоентропійних) твердих розчинів. За результатами досліджень можна зробити такі висновки.

1. У мультишарах, в яких чітко зберігається індивідуальність окремих немагнітних і магнітних шарів, у результаті СЗРЕ на інтерфейсах реалізується ефект ГМО, амплітуда якого збільшується під час зменшення температури вимірювання.

2. У мультишарах або багатошарових плівкових системах, в яких має місце необмежена або частково обмежена розчинність елементів, може реалізуватися як звичайний анізотропний магнітоопір за відсутності або суперпарамагнітного характеру гранул, так і ефект ГМО при однодоменному або багатодоменному характері наногранул, на яких реалізується СЗРЕ; амплітуда ефекту також визначається температурою вимірювання і загальною товщиною зразка. 
3. У гранульованих плівкових сплавах, сформованих під час одночасної або пошарової конденсації магнітних і немагнітних компонент зі значною взаємною розчинністю, утворюється система магнітних гранул, на яких реалізується СЗРЕ i, як наслідок цього, ефект ГМО.

4. У високоентропійних плівкових сплавах спостерігається як анізотропний, так i гігантський магнітоопір; їхня висока температурна стабільність дозволяє розглядати ВЕС як потенціальний магніторезистивний матеріал електроніки.

Робота виконана в рамках держбюджетної тематики Міністерства освіти і науки України № $0118 \mathrm{U} 003580$ (2018-2020рp.).

\section{АНОТАЦІЯ}

У роботі проаналізовані літературні дані та результати власних досліджень магніторезистивних властивостей плівкових систем із різною архітектурою. Розглянуті три типи плівкових матеріалів, які знаходяться широке застосування в електроніці та сенсорній техніці. Мова йде про багатошарові системи, в т.ч. мультишари; гранульовані та багатокомпонентні (високоентропійні) плівкові сплави. Описана методика отримання цих трьох типів матеріалів, контролю їх фазового i елементного складу та вимірювання магнітоопору. Проаналізовані умови реалізації анізотропного та гігантського магнітоопору. Підкреслюється, що ці ефекти мають важливе значення 3 точки зору прикладного аспекту фізики i техніки плівкових матеріалів.

\section{ЛІТЕРАТУРА}

1. Campbell I.A., Fert A. Transport properties of ferromagnets. Ferromagnetic Materials. Edited by E.P. Wohlfarth. 1982. V. 3. P. 747-800.

2. Grunberg P., Schreiber R., Pang Y.,. Brodsky M.B, Sowers H. Layered magnetic structures: evidence for antiferromagnetic coupling of Fe layers across Cr interlayers. Phys. Rev. Lett. 1986. V. 57, № 19. P. 2442-2445. DOI 10.1103/PhysRevLett.57.2442.

3. Ферт А. Происхождение, развитие и перспективы спинтроники. Успехи физических наук. 2008. Т. 172, № 12. C. $1336-1348$.

4. Berkowitz A. E., Mitchell J.R., Carey M. J., Young A.P., Zhang S., Spada F.E., Parker F.T., Hutten A., Thomas G. Giant 
magnetoresistance in heterogeneous Cu-Co alloys. Phys. Rev. Lett. 1992. V. 68, № 25. P. 3745-3748. DOI 10.1103/PhysRevLett.68.3745.

5. Грюнберг П.А. От спиновых волн к гигантскому магнитосопротивлению и далее. Успехи физических наук. 2008. Т. 172, № 12. С. 1349-1358.

6. Tiwari A. Effect of addition of $\mathrm{Ni}$ on the structure and giant magnetoresistance in $\mathrm{Fe}-\mathrm{Cu}$ films. Physica B: Condens. Matter. 2007. V. 387. P. 63-68. DOI 10.1016/j.physb.2006.03.029.

7. Hiep V.V., Chau N., Hong D.M., Luong N. H. High coercivity and giant magnetoresistance of $\mathrm{CoAg}, \mathrm{CoCu}$ granular films. J. Magn. Magn. Mater. 2007. V. 310. P. 2524-2526. DOI 10.1016/ j.jmmm.2006.11.136.

8. Yeh J. W., Chen Y. L., Lin S. J., Chen S. K. High-Entropy Alloys - A New Era of Exploitation. Mater. Sci. Forum. 2007. V. 560. P. 1-9. DOI 10.4028/ www.scientific.net/MSF.560.1.

9. Vorobiov S.I., Kondrakhova D.M., Nepijko S.A., Poduremne D.V., Shumakova N.I., Protsenko I.Yu. Crystalline structure, electrophysical and magnetoresistive properties of high entropy film alloys. J. Nano- Electron. Phys. 2016. V. 8, № 3. P. 03026-1-03026-5. DOI 10.21272/jnep.8(3).03026.

10. Bereznyak Yu.S., Opielak M., Odnodvorets L.V., Poduremne D.V., Protsenko I.Yu., Shabelnyk Yu.M. Crystalline structure and physical properties of high-entropy film alloys. J. Nano- Electron. Phys. 2019. V.11, №2. P. 02026-1-02026-6. DOI 10.21272/jnep.11(2).02026.

11. Yeh J.-W. Recent progress in high-entropy alloys. Ann. Chim. Sci. des Matériaux. 2006. V. 31. № 6. P. 633-648. DOI 10.3166/acsm.31.633-648.

12. Arana S., Castafto E., Gracia F.J. High temperature circular position sensor based on a giant magnetoresistance nanogranular $\mathrm{Ag}_{\mathrm{x}} \mathrm{Co}_{1-\mathrm{x}}$ alloy IEEE Sens. J. B. 2004. V. 4. P. 221-225.

13. Baibich M.N., Broto J.M., Fert A., Vandau F.N., Petroff F., Eitenne P., Creuzet G., Friederich A., Chazelas J. Giant magnetoresistance of (001)Fe/(001)Cr magnetic superlattices. Phys. Rev. Lett. 1988. V. 61. P. 2472-2475. DOI 10.1103/PhysRevLett.61.2472.

14. Кондрахова Д.М., Шабельник Ю.М., Синашенко О.В., Проценко I.Ю. Структурно-фазовий стан, електрофізичні та магнеторезистивні властивості твердих розчинів у плівкових системах на основі $\mathrm{Co}$ i $\mathrm{Cu}$ або $\mathrm{Ag}$ та $\mathrm{Fe}$ i $\mathrm{Cr}$ або $\mathrm{Cu}$. Успехи физики металлов. 2012. Т. 13, № 3. С. 241-267. 
15. Koltunowicz T.N., Bondariev V., Odnodvorets L.V., Protsenko S.I., Shumakova M.O., Tkach O.P. Electrophysical properties of granular film alloys. Vacuum. 2019. V. 164. P. 165-169. DOI 10.1016/j.vacuum.2019.04.015.

16. Vrenken H., Kooi B.J., de Hosson T.M. Microstructure and properties of giant magnetoresistance granular $\mathrm{Au}_{80} \mathrm{Co}_{20}$ alloys. J. Appl. Phys. 2001. V. 89, № 6. P. 3381-3388. DOI 10.1063/1.1325381.

17. Yeh J. W., Chen S. K., Lin S. J., Gan J. Y., Chin T. S., Shun T. T., Tsau C. H., Chang S. Y. Nanostructured high-entropy alloys with multiple principal elements: novel alloy design concepts and outcomes. Adv. End. Mater. 2004. V. 6. P. 299- 303. DOI 10.1002/adem.200300567.

18. Карпець М.В., Макаренко О.С., Мисливченко О.М., Горбань В.Ф. Вплив $\mathrm{Ni}$ на фазовий склад, мікроструктуру та механічні властивості системи високоентропійних сплавів $\mathrm{AlCrCoCuFeNi}$ ( 0,5; 1; 2; 3). Наукові вісті НТУУ «КПІ». 2014. Т. 2. № 46. С. 46-52.

19.Калініченко С.М., Ткач О.П., Гричановська Т.М., Однодворець Л.В. Терморезистивні властивості плівкових твердих розчинів на основі $\mathrm{Cu}$ та Ni. Ж. нано- та електронної фізики. Т. 7, № 4. 2015. C. 04048-1-04053-5.

20. Мазур Ю.П., Остапенко Р.В., Семенько М.П. Вплив різних типів деформацій на електроопір високоентропійного стопу $\mathrm{CrMnFeCoNi.} \mathrm{Наносистеми,} \mathrm{наноматеріали,} \mathrm{нанотехнологіï.} 2016$. T. 14. № 4. C. 539-551.

Information about authors: Odnodvorets L. V.,

Doctor of Physical and Mathematical Sciences, Professor, Professor of Electronics, General and Applied Physics Department Sumy State University 2, Rymskyi-Korsakov Str., Sumy, 40007, Ukraine

Protsenko I. Yu.,

Doctor of Physical and Mathematical Sciences, Professor, Chairman of Electronics, General and Applied Physics Department Sumy State University 2, Rymskyi-Korsakov Str., Sumy, 40007, Ukraine 